DOI

http://dx.doi.org/10.1590/2236-463320151004

Experiencias de tiempo y cambio

conceptual en el proceso revolucionario

rioplatense (1780-1840)

\title{
Experiences of Time and Conceptual \\ Change in the Río de La Plata \\ Revolutionary Process (1780-1840) ${ }^{12}$
}

\section{Fabio Wasserman}

Instituto Ravignani - Conicet, Buenos

Aires - Buenos Aires, Argentina

e-mail: fwasserm@gmail.com
1

Preliminary versions of this text were presented at the Colóquio Internacional Experiencias de Tempo nos Século XVIII y XIX, University of São Paulo, between 23 and 25.04.2014 and at the Seminario abierto de discusión del Posgrado en Historia of the University of San Andrés, Buenos Aires, 09/24/2014. I appreciate the comments made by the participants in both events. 2

This work was translated by Juliana Jardim de Oliveira e Oliveira (jujardim84@gmail.com), History PhD candidate at the graduate program of the Federal University of Ouro Preto, Brazil.

\begin{abstract}
From a "conceptual perspective", this article analyzes how the elites in the Río de la Plata transformed their experience of Time since the revolutionary process that started in 1810 . Based on a comprehensive corpus of documents it examines: a) the Revolution as a break with the past and the beginning of a new era, marked by the velocity and intensity of events and a future-oriented perspective; b) the relationships between Temporality and Politics; and c) the development of a new concept of Time.

\section{Resumen}

El trabajo analiza desde una perspectiva conceptual cómo las elites rioplatenses procesaron la nueva experiencia de tiempo provocada por el proceso revolucionario iniciado en 1810 . El examen, que se basó en un corpus documental amplio, se centró en tres puntos: a) la consideración de la revolución como una ruptura con el pasado y el inicio de una nueva época signada por la velocidad e intensidad de los acontecimientos y por tender su mirada hacia el futuro; b) la relación entre temporalidad y política; c) la elaboración de un nuevo concepto de tiempo.
\end{abstract}

\section{Keywods}

Conceptual History, Intellectual History, Temporality, revolution, Río de la Plata, Nineteenth Century

Palabras clave

Historia Conceptual, Historia Intelectual, Temporalidad, revolución, Historia Rioplatense, siglo XIX 
(...), revolution implies a revolution in time. The revolution involves a revolution of time. There is nothing that succeeds in time, but time is part of what must be revolutionized. After the revolution, time is no longer what it was. It is necessary to see both things: how revolution passes through time and what happens to time due to the revolution. Moreover, it should be established whether the predominance of the present over the past is stipulated as a condition of revolutionary thought or, conversely, as a cosmovision that only revolution could make possible.

[Martin Kohan, Museum of the Revolution]

3 For an analysis and narrative of the May Revolution and of the period here considered, you may consult the following texts following the more recent historiographical contributions: FRADKIN, Raúl; GARAVAGLIA, Juan Carlos. La Argentina colonial. El Río de la Plata entre los siglos XVI y XIX. Buenos Aires: Siglo XXI, 2009; GOLDMAN, Noemí (dir.). Revolución, República, Confederación (1806-1852). Buenos Aires: Sudamericana, 1998. TERNAVASIO, Marcela. Historia de la Argentina 1806-1852. Buenos Aires: Siglo XXI, 2009

4

LA GACETA DE BUENOS AYRES. Buenos Aires, n.108, 25/5/1814. ("Si computamos el tiempo no por su duración abstracta, sino por la calidad y número de los sucesos grandes, hoy debemos celebrar el aniversario de cuatro centurias, al ver que los acontecimientos de nuestra edad han llenado ya el profundo vacio que dejaron en su lóbrego periodo las generaciones anteriores").

\section{Introduction}

In may $18^{\text {th }}$ of 1810 it was officially spread in Buenos Aires a piece of news that would have vast and unpredictable consequences over both sides of the Atlantic: the Central Junta that had governed the domains of the Spanish monarchy had been dissolved after the triumph of the French arms. Part of the elite that had the support of the criole militia, led by Cornelio Saavedra, forced the convocatory of an open Cabildo that imposed the thesis of the retroversion of sovereignty to the people and the creation of a self-ruled government. In view of a failed attempt of the viceroy Baltasar Hidalgo de Cisneros to remain in power, on the $25^{\text {th }}$ a provisory junta was elected under the presidency of Saavedra who should govern the Río de la Plata viceroyalty on behalf of the people and of Fernando VII, the captive monarch since 1808. These events, which came to be known as the May Revolution, had outset the process of separation between the people of the Rio de la Plata and the Spanish monarchy. ${ }^{3}$

In May 1814, while Buenos Aires celebrated the fourth anniversary of the revolution that had converted into a war of independence with revolutionary focus in almost all Spanish America, the official newspaper published an article in which the author argued that:

If we compute time not by its abstract duration but by the quality and number of great events, today we celebrate the anniversary of four centuries, considering that the accomplishments of our time have filled the profound gap left by the previous generations in the gloomy preceding periods. ${ }^{4}$

These words were not the result of a reflection on the nature of time. In fact, the claim that those four years amounted to four centuries "not by its abstract duration, but by the quality and number of great events", had a more urgent motivation: to account for the intensity of the revolutionary experience marked by a succession of unexpected and vertiginous events. This unprecedented and uncertain state of things demanded the mobilization and the reformulation of the available intellectual and symbolic resources and the creation of new ones. There was an urgent necessity to interpret each one of the new events, but also, and especially, to make intelligible the general meaning of the revolutionary process. As the quotation exposes, this also involved making sense of a new experience of time, or at least making a change in what had been considered until then as its natural course.

Parting from a conceptual perspective, this paper will analyze how the Rioplatense elites grappled with this new experience of time. Since this is an initial approach to this problem, I have chosen to focus on transformations of political order. However, this does not mean that we do not acknowledge the technological, scientific, economic, social, and cultural 
5

According to Koselleck "(...) every paraphrase of time in itself always involves a linguistic exercise of great abstraction because time escapes observation. (...) The past can be displayed. However, the intertwining of future, past and present that occurs in humans, cannot be observed because it does not speak of the future considered in itself". Meanwhile, Elias argues that it is a "(...) concept of a high level of generalization and synthesis", and due to it, he "avoids talking about 'level of abstraction"', since "from what the concept of time would be abstracted?". KOSELLECK, Reinhart. Progreso y Decadencia. Apéndice sobre la historia de dos conceptos. In: _. Historias de conceptos. Estudios sobre semántica y pragmática del lenguaje político y social. Madrid: Trotta, 2012. p.97. ELÍAS, Norbert. Sobre el tiempo. Madrid: FCE, 1989. p.51.

6

The definitions can be found in the webpage of the Real Academia Española, which includes dictionaries since the 15th century. Available in: $<$ http://ntlle.rae.es/ntlle/SrvltGUILoginNtlle>.

7

FERNÁNDEZ SEBASTIÁN, Javier. Cabalgando el corcel del diablo. Conceptos políticos y aceleración histórica en las revoluciones hispánicas. In:___ _ CAPELLÁN DE MIGUEL, Gonzalo (eds.). Conceptos políticos, tiempo e historia. Santander: Universidad de Cantabria McGraw-Hill Interamericana de España, 2013. p.429. factors that transformed the social, working and family life between the eighteenth and nineteenth centuries. However, beyond the appreciations that we could develop on these themes, in truth this approach would demand counting on studies on a variety of topics scarcely dealt with. Besides, it would be necessary to consider a much larger period of time to account for their impact.

Before beginning our analysis, it is necessary to define some of the problems and challenges that have guided this research and the hypothesis that prompted it. Initially we are faced with an heuristic problem: building a corpus that will allow us to address such an elusive concept as time, a quality that some authors attribute to time due to its high degree of abstraction and others, to its high level of generalization ${ }^{5}$. This may be the reason why dictionaries from the period offered numerous examples of its uses, as if uses could not be easily detached from definitions such as "the successive duration of things" or "the measurement of the duration of things"6. It is a concept that is usually expressed by a diversity of voices, and whose examination even more than in other cases, deserves great attention to its semantic fields and to close concepts, such as providence, regeneration, progress, revolution, decadence or history. It is also necessary to consider the many metaphors referring to time and the forms of referring to it though phrases that are frequently associated to a spatial character, such as close or far. The revolution in the Río de la Plata has an additional difficulty, although this has probably also affected other contemporary processes: the scarce number of reflections on the concept of time, in opposition to what happened to other political concepts, such as homeland, revolution, people, nation. This might have been due to the fact that the bulk of the discursive production in the period had a political and contextual character - official documents, press, poems, speeches, sermons - while a concept of this nature is usually treated in works of greater scope, such as philosophical, theological, or scientific essays.

The second problem, of analytical scope, is the need to distinguish phenomena that are intertwined and may cause confusion when we examine the relationships between experiences of time and revolution in the eighteenth and nineteenth centuries. The first phenomenon, expressed in phrases like "old regime" or "new order" is to consider the revolution as a rupture between two qualitatively different periods in social and political terms. The second phenomenon is to characterize these periods not only as being animated by conflicting principles but also for presenting another dynamic and for having a different relationship with the past and the future: whilst that pre-revolutionary society could be characterized by a static order that would only admit slow changes and was surrendered by the cult of the past, the new era is distinguished by the speed and intensity of events and for extending its vision to the future. The third phenomenon is the development of a new concept of time as a result of the innovations brought about by the revolutionary rupture.

This distinction led to three hypotheses. The first is that those years produced a temporalization of politics and a politicization of time ${ }^{7}$. The second is that the revolution affected the perception of time when considering that a new era was being lived, marked by the acceleration and the opening of a new horizon of expectations irreversibly distanced from the past. The third is that the impact, besides its sharpness, was not a sufficient condition to forge a new concept of time. 
To specify how, when, and why these conditions occurred is beyond the scope of this paper. This is why I will only present two conjectures to which I will return briefly in my final considerations. First, the contemporaries were not clear about the acceleration as being an anomaly created by the revolution; therefore, they could expect that when the revolutionary process was concluded, time would also go back to its natural course. Second, in the beginning of the 1830s, the members of the Romantic generation disposed of a conceptual apparatus capable of giving meaning to these new events, but especially to this process of production which they considered as part of the historical movement governed by a temporality that was immanent to social subjects.

A Time of changes: between illustration and the crisis of the monarchy To measure how the revolutionary process impacted on the experiences of time and its conceptualization we must consider the previous state of things. Since the arrival of the Europeans in the beginning of the $16^{\text {th }}$ century, and for over two centuries, the Río de la Plata region had been a territory located on the margins of the Spanish empire and with little demographic, economic, institutional and cultural development. Its inhabitants lived away not only from the metropolis, but also from the American political centers such as Mexico and Lima. This marginal condition, the scarcity of literate institutions, and the fact that much of the discursive production remained unpublished until the nineteenth and twentieth centuries, helps to explain why there was no established historiographical or literary tradition of stature in the region, nor a development of a solid intellectual life as occurred in New Spain and Peru.

This scenario began to change in the second half of the eighteenth century as a result of the Atlantic reorientation of the economy, which promoted a rapid growth of Rio de la Plata coastline and increased the interest in the region by the European powers. This new reality was consolidated in 1776 with the creation of the Viceroyalty of the Rio de la Plata with its capital in Buenos Aires, which incorporated the provinces of Cuyo and Alto Peru under its jurisdiction. The economic and demographic development together with a growing and intensified connection with the world, the creation of new institutions and an increased presence of public officers imbued with reformist ideas, promoted a moderate modernization of the cultural life and the revalorization of the region, envisioning an imagined and promising future.

This process that was in development in several parts of the Spanish monarchy with varying intensity, led to an emerging public debate protagonized by those who proposed to replace archaic practices by new practices that had been useful and rationally based. Manuel Belgrano was one of the main enthusiasts of this movement and a future revolutionary leader. Faced with the lack of literate institutions such as universities, colleges, or patriotic societies, he decided to use his position as Secretary of the Consulate of Buenos Aires to spread these reformist ideas. In 1796 he presented a Memory Sobre los medios generales de fomentar la agricultura, animar la industria y proteger el comercio en un pais agricultor, in which the physiocratic key would account for an inherent temporality of nature:

In all ancient people it has been the delight of great men and even so, this same nature seems to have been complacent and complies that men are destined to 
8

BELGRANO, Manuel. Escritos Económicos.

Buenos Aires: Raigal, 1954. p.65 ("En todos los pueblos antiguos ha sido la delicia de los grandes hombres y aun la misma naturaleza parece que se ha complacido y complace en que los hombres se destinen a la agricultura, y si no ¿por quién se renuevan las estaciones? ¿Por quién sucede el frío al calor para que repose la tierra y se reconcentren las sales que la alimentan? Las Iluvias, los vientos, los rocíos en una palabra, este orden admirable e inmutable que Dios ha prescripto a la naturaleza no tiene otro objeto que la renovación sucesiva de las producciones necesarias a nuestra subsistencia").

Ibidem, p.108 ("que ni el labrador, ni el comerciante ni el artista ignore lo que les corresponde, que unos y otros procuren no apegarse tan intimamente a los pensamientos de sus antepasados, los cuales sólo deben adoptarse cuando convienen, y cuando no, desecharlos y abandonarlos: lo que fue útil en otro tiempo, ahora es perjudicial, las costumbres varian, los usos igualmente, y todo, de tiempo en tiempo cambia, sin que en esto haya más misterio que el de la vicisitud de las cosas humanas").

10

MORENO, Mariano Moreno. Memoria sobre la invasión de Buenos Ayres por las armas inglesas al mando del General Lord Beresford. Buenos Aires: Ministerio de Justicia y Derechos Humanos de la Nación, 2011. p.23. agriculture, and if not, for whom do the seasons renew? For whom does the cold succeed the heat for the earth to repose and reconcentrate the salts that feed it? The rains, the winds, the dews, in a word, this admirable and immutable order that God has prescribed to nature has no other object than the necessary renovation of the necessary productions to our subsistence. ${ }^{8}$

Without questioning this natural order, Belgrano also considered the existence of a mutable human temporality, as he sustained in the Memoria, presented two years later and which reading was attended by the viceroy Antonio Olaguer y Feliú:

\section{(...) That neither the farmer nor the tradesman, nor the artist ignore what is theirs, that one and other seek not to be so closely attached to the thoughts of their ancestors, which should be adopted only when convenient and, if not, they should be rejected and abandoned: that what was useful in the past, is now harmful, the customs vary and the uses also, and everything changes from time to time, with no more mystery into it than the vicissitude of human affairs. ${ }^{9}$}

Since 1801, the publication of newspapers in Buenos Aires favored the dissemination and the discussion of these ideas that promoted social, economic, and cultural transformations. In this context an enduring topic would take shape: the prediction of a grand destiny to the region. This promising consideration based on the political economy, gave room to a new horizon of expectations, without, however, questioning its links to Spain. It was clear to that time that the monarchy was going through a crisis, which the outcome, until then unimaginable, would subvert all expectations in both sides of the Atlantic. That is why this promising future tended to be attributed to Providence, to the qualities of the territory, to the diffusion of the Enlightment, and to the efforts of its people, rather than to the possible actions of the Crown and its officials.

All these matters - a greater importance of the Rio de la Plata region, the key role of its inhabitants, the opening of a new horizon of expectations and the crisis of the Spanish monarchy - were dramatically put in evidence with the English occupation of Buenos Aires and Montevideo in 1806/7. Mariano Moreno, who was then serving as an attorney of the Cabildo of Buenos Aires, without imagining that in 1810 he would be designated Secretary of La Junta and would eventually lead the radical faction of the revolution, wrote a memory accounting for the surprise and the significance of these events that, affecting such an important city to where so many interests converged, required a written testimony: "The desire to satisfy such a justified curiosity has impelled me to create a history of this conquest"10. The response of the population was no less surprising: after the defection of the authorities and the failure of the regular forces, militias were organized, drove out the occupants, resisted to yet another attack and obtained the British surrender and withdrawal in July 1807. The consolidation of the Creole militias reoriented the power relations between European and American Spaniards in the setting of an acute institutional crisis: an open Cabildo displaced the Viceroy Rafael de Sobremonte for his lusterless performance and appointed as his replacement the French officer Santiago de Liniers, who had led the reconquering of Buenos Aires.

The reaction to the English invasions imbued different sectors with the conviction that they had become the protagonists of these transcendental events and, therefore, worthy of remembrance. Martín de Álzaga, a tradesman of Basque origin who was a first vote mayor and played an 
11

Martín de Álzaga a Zacarías Pereyra, Buenos Aires, 16/9/1807. In: WILLIAMS ÁLZAGA, Enrique (ed.) Martín de Álzaga, Cartas (1806-1807). Buenos Aires: Emecé, 1972. p.215.
12

MORENO, Manuel. Vida y Memorias de Mariano Moreno. [Londres, 1812]. Buenos Aires: Eudeba, 1968. p.92-93 ("Se habia acabado la docilidad absoluta al régimen antiguo, mas todavia los límites de una separación completa estaban muy remotos; estaban sólo más cerca de la edad presente. En una palabra, Buenos Aires, después de sus victorias, no podía continuar en ser el teatro del capricho de la metrópoli, pero debía ser siempre una parte del imperio español.")

13

RODRÍGUEZ CASADO, Vicente; CALDERÓN QUIJANO, José Antonio (eds.). Memoria de gobierno del Virrey Abascal 1806-1816. Sevilla: Escuela de Estudios Hispano-Americanos de la Universidad de Sevilla, 1944. t.II, p.283 ("poseído el Pueblo de la quimera de una felicidad futura que habia de disfrutarse con sólo la simple declaración de una impracticable independencia, no perdia jamás de vista los medios de conseguirla aprovechándose de las circunstancias que el tiempo y los accidentes fueron presentando con oportunidad para el logro de su intento"). important role in the defense of Buenos Aires, asserted that this triumph, owed to a people who had sacrificed their interests and their lives, "(...) will constitute a memorable time in history that will serve as a model of fidelity and patriotism to all who have the good fortune to be vassals of the best monarchs and governed by the wisest laws of the world"1".

Although at that time the monarchy had accumulated one problem after another, no one could foresee what would happen shortly after: the crisis unleashed by the abdication of Bayonne and the French occupation and its aftermath, that after years of revolution and wars, resulted in the independence of great part of its American domains and in the creation of new political communities.

\section{Revolution: a new time}

The organized resistance to the English invasions caused important changes in the local political order. Nevertheless they were not sufficient to promote rupture with the metropolis, as it would arise in May 1810, when the creation of the Junta de Gobierno in Buenos Aires initiated the revolutionary process. Manuel Moreno made this radical difference and its consideration in temporal terms explicit in his biography dedicated to his brother Mariano after his suspicious death at sea in the beginning of 1811. The biography claimed that as a result of the English invasion:

\footnotetext{
The absolute docility of the old regime was over. However, the limits of a complete separation were still very remote; they were only closer to the present age. In a word, after its victories, Buenos Aires could not continue to be the theater of the metropolitan whim, but would always be a part of the Spanish empire. ${ }^{12}$
}

In a retrospective analysis of the revolutionary process, Moreno adverted that the power obtained by the local forces had not challenged the colonial order. Although time had begun to accelerate and they were "closer to the present time", he also understood that these deeds alone were not enough to achieve this new age.

Beyond the renewed horizon of expectations that the enlightened discourse produced, the modernization of the Spanish monarchy and the events that were transforming the world - the independence of the English colonies in North America, the French Revolution, the Napoleonic wars, the Industrial Revolution, technological advances and scientific findings - in the Río de la Plata it was considered that this new era was a result of the movement started in May 1810. This movement rapidly became a revolution and a war of independence that stimulated the mobilization, politicization and ideologization of vast social sectors. This rupture was a condition for the absolute possibility of reflections such as the ones by Manuel Moreno. Besides reevaluating the past and the present, his reflections converted the new north of the public life to the future. This was also critically pointed out by one the most brilliant adversaries of the revolution in South America, the Viceroy of Peru, José Fernando de Abascal. In his memories written in 1816 concerning the events in Buenos Aires after the English invasions, he noted:

\footnotetext{
(...) Possessed the People with the chimera of a future happiness that was destined to be enjoyed only with the simple statement of an impracticable independence, they never lost sight of the means to obtain it by taking advantage of the circumstances that the time and the events were presenting to achieve their intent ${ }^{13}$
} 
14

SOUTO, Nora. América (Argentina-Río de la Plata). In: FERNÁNDEZ SEBASTIÁN, Javier (dir.). Diccionario político y social del mundo iberoamericano. La era de las revoluciones, 1750-1850 [lberconceptos I]. Madrid: Fundación Carolina : Centro de Estudios Políticos y Constitucionales : Sociedad Estatal de Conmemoraciones Culturales, 2009. p.71.

15

EL CENSOR. Buenos Aires, n.2, 1/9/1815. In: Biblioteca de Mayo. Colección de obras y documentos para la Historia Argentina. Buenos Aires: Imprenta del Congreso de la Nación, 1960. t.VIII, p.6487-6488 ("Infelices siglos en que han transcurrido tantas generaciones sin que el virtuoso haya podido serlo impunemente! En que la menor queja se reputaba un delito, y una resignada sumisión se interpretada soberbia! Pero en el dia, representantes del pueblo, podréis laborar sobre otras bases distintas. Ya no es un crimen de lesa majestad el nombre adorable de la patria; y aunque nos falta una sólida instrucción para penetrar el lleno de nuestros intereses en todos sus respectos, porque nuestros padres y maestros nos extraviaron en pos de sus costumbres, sin embargo, nos sobra el deseo de atinar con medios adecuados").

16

I have adressed this issue in: WASSERMAN, Fabio. Revolución. In: GOLDMAN, Noemí (edit.). Lenguaje y Revolución. Conceptos políticos clave en el Río de la Plata, 1780-1850. Buenos Aires: Prometeo, 2008. p.159-174. Idem. Revolución (Argentina/Río de la Plata). In: FERNÁNDEZ SEBASTIÁN, Javier (dir.). Diccionario politico y social del mundo iberoamericano. Conceptos políticos fundamentales, 1770-1870 [lberconceptos II]. Madrid: Centro de Estudios Políticos y Constitucionales y Universidad del País Vasco, 2014. vol.9, Guillermo Zermeño (ed.), p.49-63. Idem. Entre Clío y la Polis. Conocimiento histórico y representaciones del pasado en el Río de la Plata (1830-1860). Buenos Aires: Teseo, 2008, third section.
If the revolution had inaugurated a new era faced towards the future, this was also due to the fact that this new era was lived and conceived as a counterpart of the old order that began to be understood as a colonial past. In that sense it was customary to blame the Spanish despotism for oppressing its colonies, forcing them into a state of poverty, ignorance and submission, expressed in images related to darkness and immobility. This analysis became a central topic in the revolutionary discourse. The protagonists of the revolution believed to be shedding light onto a new era in which this past should be buried, repudiated and forgotten. Likewise, this implied an ideologization, a politicization and a temporalization of what had been considered until then as territories, societies or administrative units: Spain came to be regarded as the past, while America was presented as an emblem of the future in which new social and political relations were to prevail. ${ }^{14}$

The negative judgment of the bonds to Spain and its temporalization were absolute and gave no margin for nuances. The colonial order was valued as an opaque totality under which a multisecular and diverse trajectory was sedimented. Thus, the revolutionaries were able to reference this experience through sentences such as old order, three hundred years or three centuries. Besides containing indicators of temporality, these expressions were also imbued of a self-evident character, being capable to convey its meanings without the need of any addition or explanation.

In the revolutionary discourse, the oppressive past and the present of struggle that enabled a future governed by new values and principles such as freedom, justice and reason, constituted two sides of the same coin. That is why comparisons between the two experiences, with the use of expressions such as "before..., but now..." became a common rhetorical and argumentative resource. In an article published in El Censor in September 1815, its editor addressed the representatives of the United Provinces reminding them of the:

\footnotetext{
Unhappy centuries in which so many generations have passed without the virtuous being able to be so with impunity! In which the minor complaint was considered a crime, and a resigned submission was interpreted as pride! But today, the representatives of the people can work on different bases. It is no longer a crime of lese-majesty the adorable name of the country; and although we lack solid instruction to fully penetrate our interests in all respects, because our parents and teachers have misled us pursuing their customs, we still possess the desire to accomplish it with the appropriate means. ${ }^{15}$
}

\section{The time of regeneration}

Approaches of this nature helped giving meaning and legitimizing the revolution by establishing a sharp difference between past and present. However, it posed a problem that is translucent in the article published in El Censor: when highlighting the oppressive and uniform character of the colonial experience, it was difficult to explain how the subject able to put an end to it could have emerged from this experience. This problem was solved - or minimized - in interpretations of the Revolution, which emphasized the monarchical crisis and then stressed the role played by the local actors in the fight for independence and the creation of a new order. ${ }^{16}$ The plot contained in these narratives demanded concepts capable of making it operative. In this sense, regeneration was a key concept. Besides giving the bases to explain how a despotic order that prevented the development of 
FUENTES, Juan Francisco. Regeneración. In: FERNÁNDEZ SEBASTIÁN, Javier; (dirs.). Diccionario político y social del siglo XIX español. Madrid: Alianza, 2002. p.603-608. SÁNCHEZ LEÓN, Pablo. Decadencia y regeneración. La temporalidad de los conceptos fundamentales de la modernidad española. In: FERNÁNDEZ SEBASTIÁN, Javier; CAPELLÁN DE MIGUEL, Gonzalo (eds.). Op. Cit., p.271-300. CASO BELLO, Álvaro. Discursos de regeneración en dos momentos constitucionales: Cádiz y el Río de la Plata, 1810-1813. Revista de Historia Iberoamericana, Madrid, vol.V, n.1, p.11-33, 2012.

18

OZOUF, Mona. Regeneración. In: ; FURET,

Francois (eds.). Diccionario de la Revolución Francesa. Madrid: Alianza, 1989. p.671.

19

CAPMANY, Antonio de. Centinela contra franceses. [Madrid, 1808]. Londres: Tamesis Book, 1988. p.138-139

20

So were those who attributed it negative connotations from an absolutist and counterrevolutionary position, as exposed in a unique dictionary written in Italy in the late eighteenth century by a Jesuit who ironically criticized the French revolutionary vocabulary, and which had several editions translated in Spain. THIULEN, Lorenzo Ignazio. Regeneración. In: Nuevo vocabulario filosófico-democrático indispensable para todos los que deseen entender la nueva lengua revolucionaria y los inicuos proyectos de los llamados filósofos regeneradores del mundo. Sevilla: Viuda de Vazquez y Compañia, 1813. p.19-20.

21

GÓMEZ, Valentín. Elogio fúnebre de Manuel Belgrano hecho por Valentín Gómez el 29 de julio de 1821. In: El Clero Argentino de 1810 a 1830. Buenos Aires: Imprenta de M. A. Rosas, 1907. t.II, p.98 ("Tan grandes atenciones exigian en los americanos una transformación repentina. La fuerza misma del movimiento debía obrar ese prodigio. El mundo lo ha visto. Del seno de la apatía y de la ignorancia brotaron hombres dotados de un genio superior que pudo suplir a la experiencia, y de una actividad infatigable capaz de acelerar la regeneración del país").

22

CIVES. Un habitante de esta ciudad a los habitantes de la provincia de Buenos Ayres, 8/5/1811. In: MAILLÉ, Augusto (comp.). La Revolución de Mayo a través de sus impresos. Buenos Aires: Comisión Nacional Ejecutiva del $150^{\circ}$ Aniversario de la Revolución de Mayo, primera serie, 1966. t.IV, p.285 ("Los memorables eventos que han acaecido en estas provincias desde el feliz día que vio erigirse su actual gobierno, han sacado a luz las muchas virtudes públicas, que hoy en día vemos generalizarse en todas las clases de sus habitantes, y que el sistema colonial como un espeso velo había tenido tan largo tiempo obscurecidas") its members had produced a revolution, it also expressed the possibility of social change and not only governmental change.

These uses for the concept were not entirely new. Although regeneration was originated from a scientific and religious semantic field, in the discourse of the Spanish enlightened reformism it had incorporated moral connotations, filled with social, economic and political contents that alluded to the end of decadence, to the revival of monarchy and to a bright future for Spain ${ }^{17}$. On their turn, the French revolutionaries employed the concept almost as a synonym for revolution to make reference to a radical transformation of society and its members ${ }^{18}$. In Spain this had led to restraints that were consolidated in 1808 when Napoleon was presented as its "regenerator". That is why in a diatribe against the French influence, the Catalan Antonio de Capmany called for the banishment of "(...) the words assembly, fair sex, detail, organize, requisition, section, result, constituted authorities, government officials, public servants and even the word regeneration that has cost us so many sighs"19. In the mark of this dispute that was as much political, ideological and military as it was symbolic and discursive, there were only two alternatives for the revolutionary Spaniards that resisted the French occupation: to repudiate the concept leaving its use to the local supporters of Napoleon or to dispute its meaning, attributing to its use a hypocritical sense. ${ }^{20}$

The Río de la Plata revolution was not affected by this dispute. It was able to extend the use of the concept that irrigated both its reformist and radical branches, as it considered that a political regeneration was being produced, implying the advent of a new era for the Americans. This interpretation presupposed the existence of virtuous subjects who had not been totally affected by the colonial experience, and whose actions had permitted society to begin regenerating. In the Elogio fúnebre, dedicated to Manuel Belgrano, in 1821, Valentín Gómez highlighted the virtues of those who had assumed the political and military leadership of the revolution, adding that:

So great attention demanded from the Americans a sudden transformation. The very strength of the movement would operate this prodigy. The world has seen it. From the breasts of apathy and ignorance sprang men endowed with a superior genius that could fulfill the experience, and with a tireless activity capable of accelerating the regeneration of the country. ${ }^{21}$

Ten years earlier, when he was part of the Junta de Gobierno, the dean Gregorio Funes from Córdoba, had published a pamphlet under the pseudonym Cives, stating that:

The memorable events that have befallen these provinces since the joyful day when the present government rose, have brought to light the many public virtues that we see today widespread in all classes of its inhabitants, and which the colonial system had for so long obscured as a thick veil.

He immediately referred to "the dawn of its political regeneration and the path to its happiness"22. Similarly, in the following year when the second anniversary of the revolution was celebrated, the Regidor of the Cabildo of Buenos Aires, Antonio Álvarez Jonte, sustained that "the third year of our political regeneration will begin, and the obligation to render to the country the honors that it will perpetuate in this new era, engages us to offer a tribute worthy of you all and appropriate for the circumstances". 
SUPLEMENTO DE LA GAZETA MINISTERIAL Buenos Aires, 29/5/1812.

FUNES, Gregorio Funes. Ensayo de la Historia Civil de Buenos Aires, Tucumán y Paraguay. Buenos Aires: Imprenta de Gandarillas y socios, 1816. t.I, p.IX-X ("guerras ruidosas, hazañas memorables, imperios destruidos o fundados, reyes muertos o fugitivos, y proyectos profundos de política o de moral, que por naturaleza entretienen y recrean el ánimo. Mi trabajo es mucho más limitado y estéril. Guerras bárbaras casi de un mismo éxito, crueldades que hacen gemir la humanidad, efectos tristes de un gobierno opresor, este es mi campo").

25

EL CENSOR. Buenos Aires, n.139, 16/5/1818. In: Biblioteca de Mayo...Op. Cit, t.VIII, p.3787 ("Mientras vegetaba Sud-América bajo la degradante legislación colonial, la vida de los colonos era tan maquinal, común y uniforme que las generaciones desaparecian sin dejar nada que pudiese recordar la historia, ni celebrar el entusiasmo de los poetas. No ha sido asi desde la gloriosa revolución; la generación actual deja a la posteridad hechos excelsos, sublimes virtudes con que ensoberbecerse").
In this "political regeneration" that for many years was continuously worshiped in the patriotic festivities and rituals performed throughout the Río de la Plata territory, there was a religious imprint expressed in words such as redemption, as did the official newspaper when reproducing the words of the Regidor and adding that it was being celebrated "(...) the glorious birth of the nation, the anniversary of its political redemption, and the glorious era of its civil liberty"23.

\section{The history of the present time}

An evidence of the radicalism of the Rioplatense revolution in the sense of its rupture with the colonial past is the almost total absence of historical accounts of the colonial times. Apparently it deserved only repudiation or disdain. In this regard it is interesting to observe the manner in which was presented the most important history of the region in those years: the Ensayo de la Historia Civil de Buenos Aires, Tucumán y Paraguay, published by Dean Funes in 1816/7. Like his contemporaries, Funes considered history as a repertoire of teachings, and therefore he states in his Preface that he would omit useless facts to focus on "(...) those that make us understand the customs, the nature of government, the inalienable rights of man, the national genius and anything that will teach us to be better". The problem is that he seemed not to believe that phenomena of this nature could be encountered in the local past, which is why he explained that his work would not live up to the ones portrayed by "historians of great nations" referring to

(...) Noisy wars, memorable accomplishments, empires destroyed or founded, murdered or runaways kings, and profound political or moral projects, which by nature entertain and recreate the spirits. My work is much more limited and sterile. Barbaric wars of almost the same triumph, cruelties that make humanity groan, sad effects of an oppressive government, this is my field ${ }^{24}$

For the dean, the utility of the entrepreneur to which he had dedicated years of effort, was limited to adding critical judgments on the Spanish domain, without being able to find in it episodes and figures worthy of emulation. This does not mean that they do not appear in El Ensayo, especially in regard to the actions of the Jesuits. But precisely because of this, his considerations in the Prologue are even more significant. They put in evidence the weight of the negative judgment of the colonialexperience.

Two years later, in the pages of a newspaper written in Buenos Aires, the Chilean clergy Camilo Henriquez celebrated the triumph of Maipu, which had triggered the liberation of their country, in the following words:

While South America vegetated under the degrading colonial legislation, the life of its colonists was so mechanical, common and uniform that the generations disappeared leaving nothing to be remembered in history, or celebrated by the enthusiasm of poets. This has not happened since the glorious Revolution; the present generation leaves to posterity magnificent facts, sublime virtues to make us proud. ${ }^{25}$

Likewise, the poet Juan Cruz Varela uttered in his Ode Por la Libertad a Lima, el 10 de julio de 1821, inspired by the occupation of the city of Lima by forces commanded by José de San Martín:

¡Cuál se goza la América, elevando cada vez más y más su digno trono 
La lira argentina o Colección de las piezas poéticas, dadas a luz en Buenos Ayres durante la guerra de su Independencia. Buenos Aires: 1824. p.343.

27

GAZETA MINISTERIAL DEL GOBIERNO DE BUENOS AYRES. Buenos Aires, n.16, 24/7/1812.

28

ZERMEÑO, Guillermo. Historia, experiencia y modernidad en Iberoamérica, 1750-1850. In: FERNÁNDEZ SEBASTIÁN, Javier (dir.). Diccionario... Op. Cit., tomo I, p.574.

29

FUNES, Gregorio. Oración patriótica que por el feliz aniversario de la regeneración política de la América Meridional dijo el Doctor Don Gregorio Funes, Deán de la Iglesia Catedral de Córdoba del Tucumán, en la de Buenos Aires, el día 25 de Mayo de 1814. In: El Clero Argentino..., Op. Cit., t.I, p.82-83

30

GAZETA DE BUENOS AYRES. Buenos Aires, n.14, 20/12/1811 ("Instalada en la capital de los pueblos libres la primera Junta de gobierno, empezó nuestra revolución a hacer tan rápidos progresos, que el que se detenía a observar su estado a los 6 meses, padecía la agradable e involuntaria ilusión de dudar, que aquella fuese la obra de sus coetáneos"). sobre las ruinas de ambición ibera!

Sus hijos, sus derechos recobrando,

el nombre abominable de colono

para siempre borraron. Nueva era,

nuevo tiempo se cuenta. La memoria

de nuestra antigua servidumbre, hundida

en el olvido yazca. Si en la historia

debe ser repetida,

que solamente sea,

porque nuestra justicia alli se lea ${ }^{26}$.

Varela evidenced the total lack of interest exerted by the colonial past; but he also demonstrated that any reference to it, should it be poetic, historical or rhetoric, had a precise function to accomplish: legitimize the revolution for putting the colonial past to an end.

Differently from the colonial past, from which nothing deserved to be rescued, the revolution had opened a "new era" that was creditor of a story worth being passed on to future generations. This was explicit by the government in October 1812 when it requested from the Dominican Julian Perdriel a "(...) philosophical history of our happy revolution, to perpetuate the memory of the heroes, the virtues of the children of South America, and the glorious period of our civil independence" ${ }^{127}$. This commission would be later transmitted to Funes, who concluded the third volume of his Ensayo with a Bosquejo de la Revolución. Beyond its results, this and similar enterprises parted from the same premise that composed the notion of contemporary history: the events of the recent years were richer in teaching than all the previous history had been. ${ }^{28}$ That is why, when celebrating the fourth anniversary of the revolution, Funes began a prayer with a comment on the First Epistle of St. Paul to the Corinthians, "today we are the spectacle of heaven and earth", further clarifying that "if Providence deigns to crown our efforts, the time of our revolution will bring us more honor in history" 29 .

\section{Time in revolution}

The only history worth telling was that of the present. However, this history was not related uniquely to a process enlivened by principles and interests contrary to those that had prevailed in the colonial past: it should also account for a new experience of time governed by acceleration. By the end of 1811, the politician and publicist Bernardo of Monteagudo, an active militant of the most radical faction of the revolutionaries, published an article analyzing the reasons why the revolution had suffered setbacks, and attributed them to the moderate politics of Saavedra who had just been ousted from government. As a counterpart, he claimed the role Mariano Moreno had played in the previous year as Secretary of the Junta, stating that:

After the first Junta de Gobierno has been installed in the capital of the free people, our revolution has begun to make such rapid progress that, those who stopped to observe its state six months before, suffered from an involuntary and pleasant illusion of doubting that this could be the work of their equals. ${ }^{30}$

Time, Monteagudo seemed to say, had also undergone a revolution. And he was not the only one. This new experience of time tended to be processed in two ways that could not always be clearly distinguished by words. To elucidate their meaning, we must analyze other concepts and 
31

EL CENSOR. Buenos Aires, n.78, 13/3/1817. In: Biblioteca de Mayo..., Op. Cit., t.VIII, p.7013.

32

GÓMEZ, Valentín. Op. Cit., p.110.

33

BERUTI, Juan Manuel. Memorias curiosas. Buenos Aires: Emecé, 2001.

34

N.T. "The individual reason of the subjects that have been ordinary mayors and prosecutors in the city of Buenos Aires, and their governors from 1717 onwards as their viceroys". Tradução livre. rebuild their intellectual context more accurately. The first possibility was to consider that in a short period of time it was possible to produce phenomena that in the past had required many centuries to be accomplished; and to which is referred to as a cyclical concept of revolution and history as repetition. This approach was used, for example, in the affirmation that the French Revolution had in very few years verified the classical theories on the changes in the forms of government. The second possibility was to consider that besides happening faster, the facts also had a novelty character and therefore, were part of a non-repeatable course of history. Without the disappearance of the first conception, it is the latter that would finally prevail in the mid term.

There are numerous testimonies in one or another direction that allude to a new experience of time. In general and in the same way as the binomial new order/old order, these testimonies are imbued of a comparative character since one manner of making it intelligible, was to point out its difference with the past. That seems to be the case of the mentioned article in the Gazeta, in which the experiences within four years had been equivalent to four centuries. The author attributed this fact both to the revolution and to the "profound gap left by the previous generations in those gloomy preceding periods". Camilo Henriquez opened his note written in February 1817 on behalf of the celebrations of the Chacabuco victory, affirming that "Despite the alarms caused by its vicissitudes, there is no doubt that the revolution brings on us happy, great, and glorious days, which account for centuries of the forgotten times"31. Some even further extended the comparison to the history of mankind. As wrote Gómez in his Elogio fúnebre (eulogy) of Belgrano: "(...) glory that the history of our provinces in the short period of their new political life already encloses a success that in other nations have been the result of centuries"32.

The changes in the experiences of time between the $18^{\text {th }}$ and $19^{\text {th }}$ centuries were also registered in what we might consider as the materiality of texts such as the Memorias of Juan Manuel Beruti ${ }^{33}$. Initially written by an anonymous author under the title: Razón individual de los sujetos que han sido alcades ordinaries y también procuradores, en esta ciudad de Buenos Aires, y sus gobernadores, desde el año 1717 en adelante como sus virreyes ${ }^{34}$, for decades and in the form of an annals, this text had been limited to the registering of the election of local authorities. Shortly after 1777 he added a few lines accounting for the creation of the Viceroyalty and from then on he incorporated brief comments to the text. In 1790, when he was only thirteen years old, Beruti resumed his writing and turned it into a chronicle that continued until his death in the mid 1850s. In the early nineteenth century, remarkable events were increasingly mentioned and during the English invasions these mentions became reports to which he included documents and testimonies. But it was the revolution that effectively produced a qualitative change in his work. He narrated the events each year, compared facts and opinions and reflected upon them, making and issuing judgments. Beyond the heterogeneity of this work, it can be regarded as a unit of meaning in which time is understood as a succession of presents. The extension and the increasing density of its contents allow us to appreciate not only the intensification and acceleration of the experience but also its politicization, ideologization and temporalization promoted by the revolution.

However, not even those who supported the new order considered this as an entirely positive process. In effect, the understanding of the 
35

BERUTI, Juan Manuel. Op. Cit., p.196.

36

MATHEU, Domingo. Auto-biografía por Martín Matheu su hijo. In: Biblioteca de Mayo..., Op. Cit., t.III, p.2351
37

LA CRÓNICA ARGENTINA. Buenos Aires, n.26, 16/11/1816. In: Biblioteca de Mayo..., Op. Cit., t.VII, p.6372 ("Una de nuestras mayores desgracias en el curso de la regeneración de estos pueblos ha consistido en que la multitud de los varios sucesos no nos deja experiencia alguna. Tal vez nuestro ánimo demasiado susceptible de novedades, o siempre ocupado de objetos que no son del interés común, ha divagado en una esfera que no pertenece a la huella de los sucesos mismos, y los vestigios de estos, tan débiles como plantados en la arena, se escapan o confunden en nuestra memoria alterada. Podria decirse que sin pensar bastantemente en lo presente, siempre entramos en lo futuro ignorantes de lo pasado, y que el tiempo no tiene entre nosotros bastante imperio para mesurar su existencia. Él pasa sobre nuestras cabezas como el pie fugitivo sobre un terreno que no cede a impresiones. De aquí la gran facilidad con que se extienden ciertas falsas doctrinas, sin hacernos más cautos para lo sucesivo. Con la misma facilidad vuelven a renovarse cuando han pasado algunos meses, y vuelven también a sorprendernos. Aunque quejosos de los males, cuyas fuentes no alcanzamos a ver sino en algunos visos de luz, jamás nos detenemos a considerar la historia de nuestros propios días, en que nos mostramos totalmente extranjeros"). revolution as a creator of conditions that favored society coexisted with opposite views that questioned it. Many of these novelties expressed conflicts, changes in government or government policies that generated doubts and uncertainties, perplexity and distress. Beruti, for example, stated these transformations in many passages, and many times he affirmed that they continuously surprised him not necessarily for the better. Thus, at the end of 1811, while Monteagudo celebrated the rapid progress of the revolution, despite the factious conflicts that had divided it, Beruti regretted these conflicts affirming that "(...) in this political metamorphosis, the men of court and of representation have been abated; and the common people of the plebe, though not generally, have been ennobled and occupy ranks of the first order" ${ }^{\prime 35}$. Domingo Matheu, who had been elected a spokesman of the Junta de Gobierno in May 1810, remembered the fall of Saavedra, resourcing to a traditional topic figuring the relationship between time, revolution and the fate of its protagonists: "Saturn begins to devour his children; and in Saavedra and in the idea of May, the maxim is true: 'that who opens the door to revolution is not the one to close it'"'36.

This negative assessment extended over the years and with the deepening of the factional, ideological and regional struggles, affecting the concept of revolution, which expressed a process that was to bring freedom and independence and, at the same time the dissidences that prevented it to achieve those objectives. At the end of 1816, in the context of the debate on the form of government that was to be adopted after the declaration of independence of the United Provinces of South America, the publicist Vicente Pazos Kanki evidenced this uneasiness in a sharp reflection on the relationship between experience, temporality, knowledge and politics:

One of our greatest misfortunes in the course of the regeneration of these people has been that the multitude of the many events does not leave us any experience. Perhaps our spirits, far too susceptible to the novelties, or always occupied with matters that are not those of common interest, have drifted into a sphere that does not belong to the trail of the events themselves. And its vestiges, faint as if planted in sand are escaped or confused in our altered memory. It is possible to say that if we do not think enough about the present, we will always enter the future in ignorance of the past, and that among us, time is not imperious enough to measure its existence. It passes over our heads like a fugitive foot over a land that does not yield to impressions. And so, the great facility with which certain false doctrines spread, without making us more cautious for the future. With the same facility they are again renewed after a few months, surprising us once more. Although we complain of the evils, which sources we fail to see but under a ray of light, we shall never be detained in the consideration of the history of our own time, in which we appear to be totally foreign (...)" ${ }^{\prime \prime 3}$.

For Pazos Kankiel time advanced so rapidly that the changes could not be processed and the facts left no experience. Although he could not fully explain the causes of this phenomenon, he risked attributing them to a "spirit far too susceptible to novelties". Beyond the weight this subjective disposition might have had, what society was in fact experiencing was the discovery of politics and with it, contingency. Hence the imperious character of a "history of our time", not only as a celebration or as a model to be followed, but also as an issue to be considered and processed. However, it was precisely for that reason that writing a history of the present rendered so difficult, since it was constantly overwhelmed by new facts that prevented giving it closure and a fulfilled meaning. 
38

DI STÉFANO, Roberto. Lecturas políticas de la Biblia en la revolución rioplatense (1810-1835). Anuario de Historia de la Iglesia, Pamplona, n.12, p.201-224, 2003.

39

CID, Gabriel. Las señales de los últimos tiempos. Laicidad y escatología en el pensamiento católico hispanoamericano del siglo XIX. Hispania Sacra, Madrid, vol.66, n.133, p.179-207, 2014.

40

However, it is not the same phenomenon, because shortening involves a contraction of time in a strict sense (the year becomes month, the month becomes week and the week become day); Instead, acceleration is the increased production of events without altering the objective measurement of time. KOSELLECK, Reinhart. Acortamiento del tiempo y aceleración. Un estudio sobre la secularización. In: Aceleración, prognosis y secularización. Valencia: Pretextos, 2003. p.37.

41

N.T. "The coming of Messiah in Glory and Majesty".

\section{Between Providence and Progress}

The rapid succession of new and controversial facts hindered the possibility of attributing meaning to them. How should they be interpreted? In which series were they inserted? Was it possible to assign them a transcendent character that would attenuate its contingency or, as it was then said, casuality?

Religion was the backbone of society, and it is not surprising that many of the supporters of the revolution considered it as a work of Providence (and by many of its enemies, as the work of the devil). The clergy played a decisive role in this regard, and in many of their writings and sermons they resorted to biblical passages, which in a way of atencipation, were used to explain the present events. ${ }^{38}$ Moreover, there were many people who, for better or worse, interpreted the revolution in an apocalyptic frame ${ }^{39}$. Besides considering the French Revolution and Napoleon as the Beast or the Antichrist, this millennial vein was encouraged by the new experience of time, for one of the announcing signs of the Parousia is precisely the shortening of time..$^{40}$ Hence the awakened interest in texts such as the Venida del Mesías en Gloria y Majestad ${ }^{41}$ written by the Chilean Jesuit Manuel Lacunza in the late eighteenth century, organized by such an illustrated man as Belgrano in its London edition of 1816. This publication was not merely propagandistic; in his intimacy, Belgrano also sustained that the progress of the revolution was the result of divine Will. In a letter to a friend after the decisive victory in the Tucuman battle, September 1812 , he stated that "(...) our cause has nothing to thank men; it is sustained by God and it is He who has saved it".

A few months earlier a counterrevolutionary plot led by Alzaga had been averted in Buenos Aires. In that occasion the editor of the official newspaper invoked "(...) the holy cause of liberty, which so gloriously sustains the American people". He added that "(...) the special Providence with which the Almighty protects it" should detain those who want to destroy "the admirable order of these events". And after reviewing the successes and advances produced in those months he referred to

(...) the majestic pace of the independence of the provinces of the Río de la Plata, vigorously destroying obstacles that have raised from ambition and despotism in the course of 26 months. Who does not see in the nature and circumstances of these events the strong arm of the Lord? ${ }^{42}$

Other examples could easily be added. In the second half of the nineteenth century, Providence continued to be evoked as explanation to political events. This can be observed in the presentation of a federalist newspaper from Mendoza, published in 1849:

But perhaps what will detain our eyes the most, shall be the varied spectacle of the political world; of its sudden changes, its amazing vicissitudes, its great upheavals, finally, under whose terrible impulse we daily observe the crumbling of the old building of institutions, laws, customs, and even of the conditions of life itself and that seem to propel humanity to the unacknowledged purposes of providence $!^{43}$

However, this enunciation may be misleading if considered literally. After decades amalgamated with explanations that attributed these changes to the human will and to historical laws, the invocation of providence could refer to a profane temporality and to expectations to be ac- 
complished in and by history itself. In fact, this is what the same newspaper did a few pages later: in the History section it explained the rudiments of chronology from a secular perspective, proposing a periodization based on the progress of freedom and civilization with milestones such as the American Revolution or facts that had shaken Europe in the previous year ${ }^{44}$.

Although since its beginning the revolution was considered an expression of the progress of mankind from the perspective of an Illustrated philosophy of history, a few more years were required for this concept to become more consistent and able to process its evils and regressions. By the mid-1820s, while Monteagudo accompanied the army led by José de San Martin in Chile, he published two articles in which he develops this interpretation. In the first one, "EI Siglo XIX y la Revolución"45 the author argued that his century had been characterized by the diffusion of the advances in superior knowledge that in the previous century had only been available to few men. He also emphasized the role of the American and French revolutions, complementing that "Spanish America could not escape the influence of the general laws that traced this march, which all political bodies, put in equal circumstances, should follow", and in sequence he comments on the local particularities:

\begin{abstract}
In the ten years of revolution we carry, we have experienced calamities and enjoyed goods we did not acknowledge before: patriotism has developed the seeds of civic virtues, but at the same time, it also created the spirit of party, which is the origin of daring crimes and fatal antipathies: our needs have increased significantly, although our resources are below them, as they are everywhere; in short, everything proves that we have changed our attitude in the social order and that we cannot remain in it, nor can we reverse to the old order without a moral disorder (...). No one can predict with certainty the stable form of our future institutions, but it can be ensured without perplexity that America will never return to being dependent of the Spanish throne. (...) We do not intend to deliver our happiness exclusively to a particular form of government and we prescind from what it shall be: but we are willing to follow the spirit of the century and the order of nature that calls upon us to establish a liberal and fair government. We know from experience the evils of despotism and the dangers of democracy (...). ${ }^{46}$
\end{abstract}

Monteagudo recognized that he could not precise how the new order would be, but the ten years of revolution allowed him to outline the path to achieve it. He also acknowledged the evils of the revolution and its setbacks, which according to him had no effect on its meaning and direction. Monteagudo considered a possible return to the colonial past to be inadmissible. In the second article, Estado Actual de la Revolución ${ }^{47}$, he deepened his analysis and affirmed that its varied valuations depended not only of the personal views of those who issued them, but also of considerations on the previous and current situations and should also contemplate the dominant expectations in each of these moments:

The current state of the revolution offers us a picture of fear and hope, energy and weakness, imposed onto the observer who is anxious to acknowledge its results. Arguments were easily found to conclude for one or another extremes; according to the propensity of that who discoursed and to the interest of that who observed the facts, and not what the facts proved themselves, but what was intended to be shown. But if you intend to deduce a general result from the set of reflections suggested by the present state, a most difficult enterprise is placed, because it is directed to solving the problem of understanding if our march is progressive or regressive in the enterprise we undertook ten years ago. The exactitude of this 
"El estado actual de la revolución ofrece un cuadro de temores y de esperanzas, de energía y de debilidad, que impone al que lo contempla ansioso de saber los resultados. Fácilmente se encuentran argumentos para concluir por cualquiera de aquellos extremos; según la propensión del que discurre y el interés que anima al que busca en los hechos, no lo que ellos prueban precisamente, sino lo que él intenta demostrar. Pero si se quiere deducir una consecuencia general del conjunto de las reflexiones que sugiere el estado presente, la empresa es de las más arduas, porque ella se dirige a resolver el problema, de si nuestra marcha es progresiva o retrógrada en la carrera que emprendimos diez años ha. La exactitud de este examen depende de la comparación que se haga entre nuestro estado actual y en el que nos hallábamos al principio de la revolución: (...). Nos persuadimos que el mejor método para formar este análisis es hacer un doble paralelo entre las necesidades intelectuales y físicas que teniamos entonces y las que sentimos ahora; y entre los medios de satisfacer las que estaban a nuestros alcances bajo el sistema colonial y los que hoy contamos a pesar de la imperfección de nuestro régimen. (...) El corto espacio de diez años ha bastado para causar una transformación tal entre nosotros, que si un viajero observador hubiese examinado antes estos países y volviese a ellos ahora, después de haberse ausentado en la víspera del dia que parecimos hombres por la primera vez, con dificultad se persuadiría que estas eran las regiones que habia visitado anteriormente".

49

MONTEAGUDO, Bernardo de. Estado actual de nuestra Revolución In: HERRERO, Fabián. Op. Cit., p.93-102 [EL CENSOR DE LA REVOLUCIÓN. Santiago de Chile: Imprenta del Gobierno, 10/7/1820] ("ha aumentado nuestras necesidades intelectuales y ellas son otras tantas adquisiciones que hemos hecho: ha multiplicado nuestras necesidades físicas y en la misma razón se han extendido nuestros recursos: la fortuna de un corto número de opulentos ha desaparecido, pero la subdivisión de las propiedades ha sacado de la miseria a la mayor parte y enriquecido al país: hemos sufrido y aun tenemos que sufrir grandes conflictos, pero ya estamos en marcha a nuestro nuevo destino y no podemos retrogradar, sin que se extingan las impresiones físicas y morales que han dejado en nosotros diez años de revolución y de experiencia").

50

CRÓNICA POLITICA Y LITERARIA DE BUENOS

AIRES. Buenos Aires, n.95, 6/9/1827 ("arte maravilloso que atraviesa los intervalos de tiempos y distancias, y distribuye igualmente a todos los hombres los conocimientos más diversos. Sin salir de casa podemos saber lo que pasa en todo el mundo, y lo que pasó en las épocas remotas (...) De las grandes ciudades de Europa, como de otras tantas hogueras inextinguibles, el fuego sagrado del saber se esparce con rapidez incalculable, y pasa a los paises más lejanos. Lo que un modesto periodista confía al papel en Edimburgo se trasmite como la chispa eléctrica a las orillas del Ganges y de la Plata, al pie de los Alpes y de los Andes. (...) La descripción de un establecimiento útil a la humanidad atraviesa los mares y va a fecundar el germen de la imitación en medio de los pueblos jóvenes en la vida social"). examination depends on the comparison made between our current state and where we stood at the beginning of the revolution (...). We are convinced that the best method for this analysis is to create a double parallel between the intellectual and physical needs we had then, and the ones we have now; and between the means of satisfying the needs within our scope under the colonial system and the means we have today, despite the imperfection of our regime. (...) The short space of ten years has been enough to cause such a transformation among us, such that if a traveller had examined these countries before and returned to them now, having left on the eve of the day we became men for the first time, he would arduously be persuaded that they were the same places. ${ }^{48}$

These words were followed by an extensive review of the transformations that had taken place, which besides confirming his judgments, allowed him to conclude that the revolution:

\section{(...) Has increased our intellectual needs and there are so many acquisitions we} have made: our physical needs have increased and in the same ratio our resources have spread: the fortune of few wealthy has disappeared, but the subdivision of the properties has taken from misery the greater part and has enriched the country: we have suffered and we shall still suffer great conflicts, but we are already in march towards our new destiny and we cannot regress without extinguishing the physical and moral impressions left on us over ten years of revolution and experience. ${ }^{49}$

In short, Monteagudo considered that the revolution was not just a sum of more or less fortunate events, but also the expression of a universal, progressive and irreversible historical force. That is why any regression could only be partial and temporary. It had also created a new state of things in the social, political and moral order, and in the economic and cultural order, in articulation with renewed horizons of expectations, promoting intellectual and material needs that could not have been imagined until then.

From this perspective, acceleration also implied a progressive homogenization of humanity. Marginal regions could be placed as equals with the central regions, or at least closer to them. The acceleration of time was followed by a contraction of space. It was assumed that both time and space were shortened as the Lights and Civilization expanded with the movement of people, goods, and ideas. In this sense, they highlighted the role of transportation and communication, and especially of the press, which transmitted knowledge and broadened the public able to access it. In an article published shortly after arriving in Buenos Aires in 1827, the liberal Spanish José Joaquin de Mora and the Neapolitan Pedro de Angelis celebrated the rapid progress produced in the recent decades, referring to the press as a

(...) Wonderful art that crosses the intervals of times and distances, and that equally distributes the most diverse knowledge to every man. Without leaving our homes we are able to know what is happening in the whole world, and what has happened in ancient times (...) From the great cities of Europe, as from so many other inextinguishable bonfires, the sacred fire of knowledge is scattered in incalculable speed, and is spread to the farthest countries. What a modest journalist trusts to a newspaper in Edinburgh is transmitted as an electrical spark on the banks of the Ganges and La Plata, at the foot of the Alps and the Andes. (...) The description of an establishment useful to humanity crosses the seas and fertilizes the germ of imitation among the young people in the social life..$^{50}$

Likewise, when a few years earlier the poet and professor of philosophy Juan Chrisóstomo Lafinur announced the release of a new newspaper 
Prospecto de EI Verdadero amigo del país, Mendoza, mayo 1822. In: ROIG, Arturo Andrés. La filosofía de las luces en la ciudad agrícola. Mendoza: Universidad Nacional de Cuyo, 1968. p.53-54.

52

EL VERDADERO AMIGO DEL PAÍS. Mendoza, n.8, 19/11/1822. In: ROIG, Arturo Andrés. Op. Cit., p.48 ("Tenemos pues que combatir preocupaciones con el carácter de respetables por su antigüedad, proscribir errores recibidos por verdades y destruir habitudes de tres siglos, consagradas por la ignorancia. La escena ha cambiado y es menester cambiar nuestro modo de existir y obrar en sentido contrario al de nuestros padres. Si se exceptúa la Religión, (...), es preciso olvidar todo lo que aprendimos de ellos, (...). Si queremos ser libres es menester romper todos los hilos de esta espantosa trama y preparar el camino hacia la prosperidad por una nueva educación").

53

EL VERDADERO AMIGO DEL PAÍS. Mendoza, n.11, 23/12/1822. In: ROIG, Arturo Andrés. Op. Cit., p.67 ("Llegó el siglo 19 en que todo hombre puede raciocinar e investigar lo que sus antepasados no descubrieron. Su espiritu es hacer libres los hombres y conducirlos por senderos más amplios y menos oscuros, que cada uno obre por el conocimiento de su razón y no por rutinas apolilladas; inflamado el corazón humano con tan risueño prospecto, cada hombre es una revolución (...) Solo los que componen las miserables y carcomidas reliquias de una edad que ya no existe, idólatras del quietismo y de la estupidez, acostumbrados a mandar sobre los espíritus y los cuerpos sin otros títulos que la ignorancia y la hipocresía, se oponen a la marcha que el Omnipotente ha delineado y quieren hacer retrogradar ese orden de la naturaleza, cuyos secretos ignoran. ¡Insensatos! ¡Pretenden volver a las tinieblas a los que han visto la luz y a la esclavitud a los que han gustado de la libertad! (...) La opinión que en el siglo pasado era de pocos es hoy la opinión general: a ésta, jamás hubo un poder que la esclavizase. Adviertan esos pigmeos que quieran hacer prevalecer sus caprichos, que no es un pueblo, no es una nación sola la que ha echado el fallo a las rutinas y a los rutineros, es el mundo entero"). in Mendoza, he praised "This sublime art [el tipográfico] that imprisons time in its velocity so we may talk to those who lived two centuries before us, is the same by which we can deliver our history and prevent the behavior of our children"51. Lafinur also regarded humanity as the subject of a process of progressive and irreversible changes towards emancipation. In that sense he understood that all the vestiges of a past that might impair this march should be put to an end:

Therefore, we must fight concerns that are considered respectable for its antiquity, proscribe errors received as truths and destroy habits three centuries old, consecrated by ignorance. The scenario has changed and it is necessary to change our way of living and acting in the opposite direction that our parents did. Apart from religion, (...) we must forget everything we learned from them (...). If we wish to be free we must cut through all the threads of this awful story and pave the way to prosperity by a new education. ${ }^{52}$

Lafinur understood that one of the hallmarks of his century was having allowed that knowledge and discoveries were made available to all men. He considered that it was not only possible but also necessary to accelerate the march of history promoting new changes:

The 19th century arrived, in which every man may reason and investigate what their ancestors had discovered. Its spirit is to free all men and lead them through broader and brighter paths, that each man will act on the knowledge of reason and not by moth-eaten routines; inflamed the human heart with such cheerful prospect, every man is a revolution (...) Only those who compose a miserable and ancient relics of an age that no longer exists, idolaters of quietism and stupidity, accustomed to command the spirits and bodies with no titles other than those of ignorance and hypocrisy, oppose to the march that the Almighty has outlined, and wishes to regress the order of nature, whose secrets they ignore. Fools! They intend to return into darkness those who have seen the light, and into slavery those who have tasted freedom! (...) The opinion that few people had in the last century is now the general opinion: to this, there was never a power able of enslaving. Warn those Pygmies who wish to prevail their whims, that it is not one village or a single nation that has made the decision to cast away the failure of the routiners, it is the whole world. ${ }^{53}$

Beyond the optimism in the progressive march that converted "every man" into a "revolution", the article evidenced that not everyone agreed with this perspective and that a struggle between the past and the future was being held. But those "pygmies" and "routiners" who opposed to the course set by the "Almighty" were now not the enemies of the revolution, but the opponents of Lafinur, whose radical reformism forced him to leave Mendoza and exile in Chile, where he died shortly afterwards.

\section{The Time of Politics}

It is from expressions such as the ones by Lafinur that we are able to support the view that the revolution produced a temporalization of politics. This is certainly a question that deserves further clarification for it is usually regarded as a distinctive phenomenon of post-revolutionary societies of modernity. Leaving aside the discussion about what would characterize modernity, including the possibility of determining it as a precise historical period, certain is the fact that every political action or reflection presupposes a conception of Time with which it is interweaved. The revolution promoted the conversion of time into a dispute as it considered that past and future expressed different values, interests, sensitivities or political and social mod- 
54

Although these words have recently come to light with the publication of his Memorias in 1830, there are serveral testimonies that account for it. PAZ, Gustavo (coord.). Desde este día adelante Revolución. Voces del 25 de Mayo de 1810. Buenos Aires: Eudeba, 2010. p.200.
GOLDGEL, Victor. Cuando lo nuevo conquistó América. Prensa, moda y literatura en el siglo XIX. Buenos Aires: Siglo XXI, 2013. els. Above all, it put into question the possibility of intervening in its march. Up to that time the prevalent conviction was that the march of time should be respected and any action forced upon it was considered inconvenient.

An example may help us illustrate this matter: the English invasions had heightened Saavedra in face of the greatest regiment of Buenos Aires and throughout 1809 he received several proposals to depose the Viceroy and create his own government. His invariable answer was that it was a hasty measure and that things should not be forced upon, for the certain triumph of Napoleon in Spain would turn this risky step into an inevitable fact. Recurring to a common expression, he alleged that waiting for the figs to ripen was the most prudent thing to do. But he also argued that when the time came, one should act immediately, without hesitation, so that no single chance would be wasted. Hence, when he learned that the Junta Central had been dissolved, his words would have been "(...) I now say not only that it is time, but also that we must not lose a single hour"54. Saavedra understood that even the most daring political decisions should follow the course of time and taken in the due moment, neither before nor after. Although his argument seemed hard to refute, it did not solve the problem of how this moment was to be determined, nor who would determine it. Therefore, it was inevitable that this decision-making was controversial even when its grounds were shared.

What changed with the revolution was that this conception was no longer unquestionable. Intervening in the march of time became a central element of political and ideological disputes. But there was more to it: while it was understood that the revolution had produced changes that otherwise would have taken centuries to occur, it also began to be considered that these events were no mere repetitions, but unprecedented facts. Therefore, besides questioning the possibility of accelerating or slowing the pace of time, it became increasingly clear that it was impossible for time to regress or to have a cyclical return.

Temporalization left a number of marks upon the political discourse. While some concepts incorporated the suffix "ism", which is an indicator of historical movement, a great number of forces, factions, institutions, practices and ideas began to be widely identified by temporal qualifications such as progressive, innovative, stationary, reactionary, conservative, retrograde. Likewise, it increased the use and the polemic weight of expressions such as spirit of innovation, innovators, fashion, or the century. Besides being used to designate cultural and social phenomena, these expressions were also invoked in the disputes concerning the valorization of the $n e w^{55}$. Over the years, the temporalization acquired an abstract character that favored its use as a framework to interpret political and ideological disputes, such as did Domingo F. Sarmiento in one of the first articles he published during his exile in Chile at the beginning of the 1840s:

\footnotetext{
To this group of men who impress their thoughts on the present moment, to which they call a generation, I will leave the task of dealing with the dominant idea of their time, or to follow its impulsion without understanding it; or, misguidedly resisting it, wishing that today was submitted to what happened yesterday, as if time were not a scale in which humanity runs, leaving behind the centuries that are their plots, and the days, as steps that from progress to progress elevate it to its mysterious table. Step by step I will see the past and the future being called as parties, for a better grip; incarnated in the people creating material forms with which dispute the empire of societies and lead each one of them in its own way, to the future that awaits. I shall see the first, praising its ancient unit, its quietude, its
} 
SARMIENTO, Domingo Faustino. Los dieciocho dias de Chile. Desde la derrota de Cancha-Rayada hasta la victoria de Maipo. In:__. Obras Completas. Buenos Aires: Luz de Dia, 1948. t.I, p.26-27 [EL MERCURIO. Valparaíso, 4/4/1841]. Original highlights ("Y dejaré a este conjunto de hombres que imprimen su pensamiento al momento presente, y que llaman una generación, ocuparse de la idea dominante de su época, o seguir su impulsión sin comprenderla; o bien, mal aconsejados, resistirla, queriendo que el dia de hoy se someta al que ayer pasó, como si el tiempo no fuese una escala, por donde corre la humanidad, dejando atrás los siglos que son sus tramas, y los días, cual escalones que de progreso en progreso la llevan ascendiendo a su misteriosa mesa. Veré de paso a lo pasado y lo presente llamarse partidos, a fin de poder asirse mejor; encarnarse en las personas para darse formas materiales con que disputarse el imperio de las sociedades y conducirlas cada uno a su modo, al porvenir que les preparan. Veré al primero, ensalzando su unidad antigua, su quietud, su gobierno paternal y su piedad religiosa, echar en cara a su adversario su revolución y sus trastornos, su desorden y su incertidumbre. Veré al segundo, ardiente y lleno de ilusiones, ostentar su ciencia su juventud, su emancipación de espíritu y sus esperanzas, culpando a su predecesor de los males que sufre, como de otros tantos escollos con que le ha embarazado la arena").

57

EL OBSERVADOR AMERICANO. Buenos Aires, n.1 19/8/1816. In: Biblioteca de Mayo..., Op. Cit., t.IX p.7656. ("En la mayor parte han sido causados por el espíritu de novedad, que temerariamente extendió su influjo a todos los ramos de la administración. Pudiera decirse que los primeros gobernantes ocupados de la grandeza del objeto, olvidaron algunos medios y algunas precauciones; dejaron de prevenir el momento más peligroso de toda revolución, que es aquel tránsito de un término a otro término, es decir, del antiguo gobierno, que se destruye al nuevo, que se establece, el cual no puede hacerse sin correr los riesgos de la anarquía, y sin un desquiciamiento general de los principales resortes de la máquina social. No advirtieron que sería mejor levantar el nuevo edificio sobre algunos muros antiguos, de los que no estuviesen débiles o ruinosos. No se contentaron con hacer las alteraciones y reformas en la parte pecante, en la parte que había ocasionado nuestros males, nuestra humillación, nuestra servidumbre, en la parte que estaba en oposición con nuestra libertad, sino quisieron descomponer, y reducir al estado de materia informe toda la masa política y civil, para combinar de nuevo los primeros elementos de la sociedad. Cada gobierno estudiaba innovaciones, que remarcasen la época de su administración. Muchas han sido necesarias por su influjo en el objeto de nuestra independencia, algunas tolerables por su indiferencia, otras perjudiciales por su inoportunidad"). paternal government and religious piety, throwing at the face of its opponent its revolution and its disorders, its disruptions and uncertainties. I shall see the second, ardent and full of hope, flaunt its science, its youth, its emancipation of spirit and its hopes, blaming its predecessor for the ills it suffers, like so many pitfalls that has embarrassed the sand. ${ }^{56}$

The valuing of the new became a matter of dispute that affected revolutionaries and counterrevolutionaries, liberals and conservatives, progressives and reactionaries according to the circumstances. One could object in more than one case, and rightly so, to the use of these labels as inadequate or anachronic. But the most important for the present issues is the fact that these cleavages could not account for one of the fundamental tensions of post-revolutionary political life: the fact that the positive valuation of the break with the past was conjugated with the fear of change and acceleration, which could undermine any attempt to build a social, moral and political order. In August 1816, a few weeks before Pazos Kanki regretted the "spirit susceptible to novelties" which affected his countrymen, the jurist Manuel Castro began the publishing of another newspaper referring to the mistakes of the revolution:

In the most part they have been caused by the spirit of innovation, which has recklessly spread its influence over all branches of the administration. One could say that the first rulers, occupied with the greatness of the object, have forgotten some means and some precautions; they could not prevent the most dangerous moment of every revolution, which is that transition from one term to another, that is, from the old government that is destroyed by the new, which is established, not without the risk of anarchy, and without a general derangement of the main resources of the social machine. They did not realize that it would be better to raise the new building over some of the ancient walls, those that were not weak or crumbling. They were not content with making changes and reforms the sinful part, that which had caused our problems, our humiliation, our serfdom, in the part that was opposed to our freedom, but they wished decompose the political and civil bodies reducing them to a formless matter to combine once again the first elements of society. Each government studied innovations that would remark the time of its administration. Many have been necessary for their influence on the object of our independence, some tolerable for their indifference, some harmful for its inappropriateness. ${ }^{57}$

According to Castro the revolution had lost its path "by the spirit of innovation" that threatened to destroy everything that had been established. He then proposed a process of transition in which innovations and tradition should be balanced. But which innovations were valid? When and how should they be implemented? These questions that were central to the political and ideological disputes were also made in reverse: what is to be made of the traditions and inherited institutions? Should they simply be preserved; were they to be amended in a gradual way, as Castro suggested; or they should be eradicated from the root, transforming "our way of existence" aside from what concerns religion, as advocated by Lafinur?

This exception was not casual. Among the innovations, one of the most conflictive was definitely religion. To celebrate the seventh anniversary of the revolution, the clergy Felipe Antonio Iriarte delivered a sermon in Tucumán criticizing those who had set aside the dogma to "(...) blindly adopt the deviations of an always restless and never infallible reason". Even worse, in that way they overtake "(...) the simplicity of the people and are presented as oracles of illustration and reform. Idleness makes them know by memory the pompous paragraphs of the heretics, repeating them with a 
IRIARTE, Felipe Antonio de. Oración patriótica que dijo el 25 de mayo de 1817 en la ciudad de Tucumán el Doctor Felipe Antonio de Iriarte. In: EI Clero Argentino..., Op. Cit., t.I, p.207-208. Original highlights.

EL CENTINELA. Buenos Aires, t.I, n.2, 4/8/1822. In Biblioteca de Mayo..., Op. Cit., t.IX, p.7939-7940.

60

Idem, n.13, 20/10/1822. In: Ibidem, p.8114. "Los cuerpos legales que nos rigen llevan en mucha parte, por no decir en todo, el sello del tiempo en que nacieron. Necesitamos otros que estén subordinados al progreso de las luces, y en conformidad con las prerrogativas de nuestra creación".

61

EL LUCERO. Buenos Aires, n.586, 24/9/1831. "No pensamos ocuparnos de cuestiones por su naturaleza inoportunas. Hablar de congreso, de constitución, es desconocer la verdadera situación del pais. Todo tiene su tiempo, y la fruta más saludable, fuera de sazón, es a veces un veneno muy activo". libertine air in gatherings and in the courtrooms". In this regard he argued that, "it is fair to flaunt about being born in the Age of Enlightenment; but to be convinced that every innovation is illustration is an extravagance" ${ }^{458}$.

However, the religious matter was not limited to the scandal that a few Voltairean spirits could make. Much more important was the dispute surrounding the role that the ecclesiastic institutions and its member should have in the new order. It is not surprising that this reform suffered the greatest resistance among the many accomplished by Bernardino Rivadavia as Minister of Government when Buenos Aires had been established as a sovereign province after the dissolution of the national authorities. In 1822 he presented a project that placed the ecclesiastic institutions under the control of the provincial government. He also dissolved orders and suppressed the tithe and the ecclesiastic courts. This project provoked a harsh debate that demonstrates the temporalization of politics. An official newspaper reproduced the arguments from its opponents, like the fact that the people had been imbued with "concerns that has consumed them for entire centuries", and concluded that "it is not time for an ecclesiastic reform". In face of these critics, the editor questioned: "And why is it not of this, as it has been of other classes? Time! For these men it is always appropriate to burden the people, and it is never appropriate to unburden them" ${ }^{59}$. On the contrary, as he argued, it was not an "untimely" reform, for the moment preserved the revolutionary impulse that had put society in movement for over a decade, promoting all kinds of innovations.

The reformists celebrated that the revolution had created a new state of things, but regretted that phenomena from different strata of time still coexisted. Thus, unlike those who were still cautious in view of the changes, some politicians and publicists promoted an urgent adaptation of the laws to the new social and political order: "The legal bodies that govern us in a great part, if not entirely, carry the stamp of the time of their birth. We need others that are subordinate to the progress of the enlightenment, and in accordance with the prerogatives of our creation" 60 .

These and other similar reflections produced a framework of factional and regional conflicts that hampered the consolidation of a stable and legitimized order for all the conflicting actors. This explained the failure of the project of national organization promoted by the unitarians during the Constituent Congress assembled between 1824 and 1827, which had elected Rivadavia as president. His centralizing actions were rejected and sparked a civil war in which the federal party triumphed. This federalist faction was led by Juan Manuel de Rosas, who governed the province of Buenos Aires from 1829 onwards and extended its hegemony to the rest of the provinces over the following years.

The negative view of the unitarian experience by the followers of Rosas led them to believe that they should wait for the course of time to create the conditions for organizing the provinces into a sovereign nation. An article published in September 1831 stated: "We do not think of dealing with issues that inopportune by nature. To talk of congress, constitution, is to ignore the true situation of the country. Everything has its time, and the healthiest fruit, out of season, can sometimes be a very active poison"61. Rosas sustained this position until the downfall of his government in 1852 and manifested it in one of his best known political texts: the letter written in 1834 to the federal caudillo from La Rioja, Facundo Quiroga, where he affirms the need to leave the organization of the people and the further 
Juan Manuel de Rosas a Facundo Quiroga, 20/12/1834, Haciendo de Figueroa (San Antonio de Areco). In: BARBA, Enrique (ed.). Correspondencia entre Rosas, Quiroga y López. Buenos Aires: Hachette, 1975. p.100. "El tiempo; el tiempo sólo, a la sombra de la paz y de la tranquilidad de los pueblos, es el que puede proporcionarlo y señalarlo".

63

EL MONITOR. Buenos Aires, n. 104, 21/4/1834. In: TAU ANZOÁTEGUI, Víctor. La codificación en la Argentina (1810-1870). Mentalidad e ideas juridicas. Buenos Aires: Imprenta de la Universidad, 1977. p.150. "No pertenecemos a la clase de los estacionarios, y mucho menos a la de los retrógrados; pero tampoco simpatizamos con los que quisieron innovarlo todo en un día, atropellando las ideas y costumbres, y ejerciendo una especie de dictadura intelectual no menos odiosa que la política (...) Cualquier innovación que se intente debe ser el fruto tardio de la persuasión; de un general y profundo convencimento".

64

N.T. "Preliminary fragment to the study of the law". 65

ALBERDI, Juan B. Fragmento Preliminar al estudio del Derecho. [Buenos Aires, 1837]. Buenos Aires: Biblos, 1984. p.130 "La democracia es, pues, como lo ha dicho Chateaubriand, la condición futura de la humanidad, y del pueblo. Pero adviértase que es la futura, y que el modo de que no sea futura, ni presente, es empeñarse en que sea presente, porque el medio más cabal de alejar un resultado, es acelerar su arribo con imprudente instancia".

66

LAMAS, Andrés. Poesías de Adolfo Berro. In: Escritos Selectos. Montevideo: Instituto Histórico y Geográfico del Uruguay, 1922. t.I, p.28. "Difícil era, repetimos, señalar el linde en que debiera contenerse el espíritu ansioso de novedades y mejoras; y dado el caso que se acertara en ello, dificil hacerlo respetar. La revolución nos había colocado sobre un plano inclinado, y el impulso fue tan vigoroso, que pasamos de un salto en política, de Saavedra a Rousseau; en filosofía del enmarañado laberinto de la teología escolástica, al materialismo de Destut de Tracy; de las religiosas meditaciones de fray Luis de Granada, a los arranques ateos y al análisis enciclopédico de Voltaire y de Holbach. Ya no fue entonces, cuestión política solamente: entraron en choque violentísimo todos los elementos sociales, y como la fuerza material es impotente para suprimir hábitos y creencias tradicionales, cumplió la revolución politica en Ayacucho, dejando la social en su aurora. Los sangrientos crepúsculos de la guerra civil son una consecuencia lógica de estos antecedentes". national organization to the course of time. In that sense, in relation to the city that should host a convention, he warned: "Time; and only time, in the shade of the peace and tranquility of the people, it is he who can provide and designate it".62

But the federalists not only blamed the unitarians for promoting wrong policies. They also accused their extemporaneous character, alleging that even if these policies were beneficial, society was not prepared for them. This argument was used by publicists of the Rosas regime to refute those who accused the governor of being reactionary. Pedro de Angelis, who had become the main voice of the rosismo, after a short passage in the Rivadavian ranks, stated that:

We do not belong to the class of the stationary, even less to that of the retrograde but we do not sympathize with those who have wanted to innovate all in one day, trampling ideas and customs, and exerting a sort of intellectual dictatorship no less odious than the political (...) Any attempted innovation must be the late bloomer of persuasion; of a general and deep convincement ${ }^{63}$.

The young Romantics of the Generation of 37 agreed in this and criticized the unitarian government for trying to impose extemporaneous reforms. In his Fragmento Preliminar al Estudio de Derecho64, Juan B. Alberdi, from Tucumán, adverted that:

Democracy is thus, as Chateaubriand stated, the future condition of humanity and of the people. Be advised, however, that it is the future condition and, the manner of making it not future or present, is to engage in making it present, because the broadest manner of impairing a result is to accelerate its accomplishment with reckless instance. ${ }^{65}$

This criticism was extended to the revolution itself. Although they claimed that the revolution had put America into the path of progress and civilization, they regretted that it had occurred when the social, moral, and intellectual conditions were not yet given. Thus, the inversion of what should have been the logical order of events had created conditions for civil war, anarchy and despotism. This was attributed to the very fact that the society was not yet prepared for some of the novelties introduced by the revolution, as the Uruguayan Andres Lamas wrote in Montevideo in 1842 , in the preface to the poetic woks of the late Adolfo Berro:

Again, it was difficult to mark the boundary that should restrain the spirit eager of innovations and improvements; and in the case of accomplishing it, it was difficult difficult to enforce it. The revolution had placed us on an inclined plane, and the impulse was so vigorous that in an impulse we jumped, in politics, from Saavedra to Rousseau; in philosophy, from the tangled maze of scholastic theology to the materialism of Destut de Tracy; from the religious meditations of Fray Luis de Granada to the atheist outburst and the encyclopedic analysis of Voltaire and Holbach. It was not then, only a matter of politics: all the social elements came into violent chocks, and because the material force has no power to suppress habits and beliefs, the political revolution was fulfilled in Ayacucho, leaving the social revolution at its dawn. The bloody sunsets of the civil war are a logical consequence of these antecedents. ${ }^{66}$

Five years earlier, during the opening of the Literary Salon that gathered the young romantics living in Buenos Aires, Alberdi had already stated the consequences of having being "placed on an inclined plane": 
67

ALBERDI, Juan Bautista. Doble armonía entre el objeto de esta institución, con una exigencia de nuestro desarrollo social; y de esta exigencia con otra general del espiritu humano. In: WEIMBERG, Félix (ed.). El Salón Literario de 1837. Buenos Aires: Hachette, 1957. p.130-131." Un dia, señores, cuando nuestra patria inocente y pura sonreía en el seno de sus candorosas ilusiones de virilidad, de repente siente sobre su hombro una mano pesada que le obliga a dar vuelta, y se encuentra con la cara austera del Tiempo que le dice: está cerrado el día de las ilusiones; hora es de volver bajo mi cetro. $Y$ entonces conocemos que mientras los libres del Norte y de la Francia no habian hecho más que romper las leyes frágiles de la tiranía, nosotros nos empeñábamos en violar también las leyes divinas del tiempo y del espacio. (...), el movimiento general del mundo, comprometiéndonos en su curso, nos ha obligado a empezar nuestra revolución por donde debimos terminarla: por la acción (...) De modo que nos vemos con resultados y sin principios. De aqui las numerosas anomalias de nuestra sociedad: la amalgama bizarra de elementos primitivos con formas perfectísimas de la ignorancia de las masas con la república representativa. Sin embargo, ya los resultados están dados, son indestructibles, aunque ilegitimos: existen mal, pero en fin existen. ¿Qué hay que hacer, pues, en este caso? Legitimarlos por el desarrollo del fundamento que les falta: por el desarrollo del pensamiento. Tal, señores, es la misión de las generaciones venideras; dar a la obra material de nuestros padres una base inteligente, para completar de este modo nuestro desarrollo irregular (...)".
One day, gentlemen, while our innocent and pure country smiled in the breast of its candid illusions of virility, it suddenly feels over its shoulder a heavy hand that forces it to turn back and it meets the austere face of Time that tells it: the day of illusions is over; it is time to come back under my scepter. And then we know that while the free men of the North and of France had merely broken the fragile laws of tyranny, we had been engaged in violating also the divine laws of time and space (...), the general movement of the world, compromising ourselves in its course, has forced us to begin our revolution from where it should have finished: by the action (...). In such a manner that we have results, but no principles. Hence the many anomalies of our society: the bizarre amalgam of primitive elements and the most perfect forms; the ignorance of the masses and the representative republic. However, since the results are given, they are indestructible, albeit illegitimate: they have a bad existence, but finally exist. What are we to do, then, in this case? Legitimize them for the development of their lacking foundation; for the development of thought. This, gentlemen, is the mission of the generations to come; to provide an intelligent base to the material oeuvre of our fathers, thus completing our irregular development (... ${ }^{67}$.

These words were as much a diagnosis as a program, for these young romantics believed they were the ones that should produce this "intelligence base", determining how, how fast, and in what direction the changes should be made. His original intention was to produce a revolution in the ideas and then in the political order. Among other reasons, this explains why Alberdi aspired being a guide to the Rosas regime, which he considered a genuine expression of the social rioplatense status. However, this strategy was put aside in 1838, when it became clear that Rosas did not account for it and a number of internal conflicts together with the French intervention predicted the end of the Rosas regime. In this context, which they believed to be unique, there was a radical change of direction and the romantics began to exert frank opposition to the regime, radicalizing their political commitments.

From then on, the romantics oscillated between these two positions, which also implicated in a different understanding of the relationship between time and politics and, more precisely, in the possibility of accelerating its march. These positions are apparently similar to what has been mentioned in the previous lines. Its meanings, however, were not the same for they were created in a context of a historicist language and of a new conceptualization of the historical time.

\section{Final Thoughts: historical time}

The revolution in Río de la Plata resulted in a new and future-oriented experience, due to its marked break with the past, acceleration and temporalization of politics. It was also a prodigious period of intellectual innovations. Contrary to what one might expect, a new conceptualization of time was not immediately forged. Again, this demonstrates that the relationship between experience and conceptual change is not necessarily direct and may require other conditions. The elucidation of why this occurred in the 1830s is beyond the scope of this work. In these final considerations I will outline its main features, proposing conjectures about its conditions.

Initially we must consider the expectation generated by the revolution regarding the dynamics of the changes that had prompted it. Many people understood that the fact that they were living a new era that would lead to a society organized under innovative principles was an irreversible process. Nonetheless, acceleration could be a conjectural phenomenon attributable to the disorders caused by the revolution, rather than a quality 
68

FUNES, Gregorio. Oración patriótica..., Op. Cit., p.66. "Verdad es que esas tempestades a que está expuesto todo Estado que se escapa de las manos de un opresor y ese espiritu de turbulencia y de desorden inseparable de toda revolución que corrompiendo el juicio aun de los más sabios, se extiende como una especie de contagio, han estado hasta aquí en oposición de nuestro común designio, y han impedido que aparezca sobre nuestro horizonte ese día claro de abundancia, de justicia y de prosperidade".

69

EL CENTINELA. Buenos Aires, n.2, 4/8/1822. In: Biblioteca de Mayo..., Op. Cit., t.IX, p.7940. "(...) el resultado final de todo lo que ha precedido, es el blanco que Buenos Aires busca con anhelo, el punto en que únicamente puede consentir el detenerse".
For a broader examination, see: WASSERMAN Fabio. "Historia (Río de la Plata/Argentina)". In: FERNÁNDEZ SEBASTIÁN, Javier. Diccionario..., Op. Cit., tomo I, p.580-592. Idem. La historia como concepto y como práctica: conocimiento histórico en el Río de la Plata (1780-1840). História da Historiografía, Ouro Preto, n.4, p.15-36, 2010. of time or a quality that would inform it henceforth In fact, this state of convulsion was precisely what some understood as the setback on a successful closure of the revolution, as Funes puts in its fourth anniversary:

The truth is that these storms to which is exposed every State that escapes from the hands of the oppressor, and this spirit of turbulence and disorder inseparable from any revolution and which, corrupting the judgment of even the wisest is contagiously spread, have been among us, opposing our common purpose, and have prevented the appearance of this bright day of abundance, justice and prosperity in our horizon. ${ }^{68}$

Almost ten years later, the editor of El Centinela defended the ecclesiastical reform alleging that it was legitimate and opportune, for it was inscribed in the movement that had been creating new things since 1810 . But he also implied that this march would be complete when the objectives of the revolution were accomplished: "(...) the final result of all that has preceded, is the target Buenos Aires eagerly seeks, the only point at which it can consent to stop"69. He could then argue that this "bright day of abundance, justice and prosperity" announced by Funes, should be the "point" at which the march would stop. Likewise, this vertiginous process of acceleration, which captivated some and frightened others, would also be concluded.

Although this expectation referred to the local process, it was part of a larger conception that presupposed the emancipation of mankind, whether it was governed by Providence or by transcendent historical laws; it envisioned a final horizon of freedom, justice and reason - and equality, for some. The romantics from Río de la Plata region also argued that mankind was governed by progressive laws and yet, they understood that this movement of indefinite perfectibility would never detain its march. Still, this was neither the only nor the most important difference in our findings. The most decisive difference was that time was no longer conceived as something abstract and external to the historical processes, which only allows to measure the movement of humanity and its progresses, to be considered as an immanent force that informed social subjects and put its evolution in motion. From this perspective, there was no time without a subject: time could only be historical.

For a better understanding of the differences between these two conceptions, I will briefly detain myself on the changes produced in the concept of History during those years. First I will draw attention to a matter that undoubtedly created favorable conditions for the intellectual renewal by the Romantics, including the conceptualization of time. I am referring to the generational experience and more precisely to the fact that they were born with the revolution and grew up in a world of constant changes. Innovations and acceleration were part of their everyday life, not just a discovery or an expectation as it had been for his predecessors. Thus, despite their criticism of the revolution and of the Unitarians, they also developed a greater sensitivity to the new, giving it a positive valuation and converting it into a generational mark associated with youth, progress and future.

Finally, let us consider what happened to the concept of History ${ }^{70}$. In the scope of the Enlightment and of the revolutionary process this concept acquired greater density and new uses, connected with its pedagogical, pragmatic and critical purposes. Despite these changes and the break with the past, History continued to be viewed as a reservoir of experiences from which lessons could be drawn, according to the assumption that every event 
is repeated in history. This clarifies why, to explain the divisions that plagued the revolutionaries, Funes had no hesitation in using a text about the French Revolution, which was interpreted in reference to the Roman classics:

FUNES, Gregorio. Ensayo de la historia civil del Paraguay, Buenos Aires y Tucumán. Buenos Aires: Imprenta de Benavente y compañia, 1817. t.III, p.492. "Un joven Ileno de talentos y conocimientos, dice un autor moderno, asombrado de leer en cada página de los antiguos el diario de lo que sucedía a sus ojos en la última revolución francesa, tuvo la feliz ocurrencia de escribirla con pasajes sacados de esos mismos autores, y sin otro trabajo que las citas compuso una obra original. ¡Tan cierto es, añade, que no hay anales más verídicos, ni más instructivos que los del corazón humano. En efecto, cuando fijamos la consideración en nuestras disensiones, no parece sino que Cicerón, Tácito y Salustio escribieron para nosotros".

72

For example, Francois Hartog demonstrates, in relation to the historia magistra that fundaments "An Historical, Political and Moral Essay on Revolutions, Ancient and Modern, considered in relation to the French Revolution" by Chateaubriand, that it "(...) translates this short moment in which, under the effect of the Revolution, the topos is no longer functional and not using it is however, still imposible" HARTOG, Fracois. Regímenes de historicidad. Presentismo y experiencias de tiempo. México: Universidad Iberoamericana, 2007. p.112.

73

FERRÉ, Pedro. Cuestiones nacionales. Contestación al Lucero ó los falsos y peligrosos principios en descubierto. Con la refutación a los autores escondidos bajo el título de Cosmopolita y Porteño, por el Gobierno de Corrientes. In: RAVIGNANI, Emilio (ed.). Documentos para la Historia Argentina. Buenos Aires: Casa Jacobo Peuser. t.XVII, p.262 [Corrientes, Imprenta del Estado, 1832]. Destacado en el original. "(...) que la prueba tomada de la historia, es incontestable en política".

74

LA LIBERTAD O EL ESPÍRITU DEL SIGLO EN BUENOS AIRES. Buenos Aires, Imprenta de los dos amigos, 1833. p.10-11 [su autoria se atribuye a Carlos Terrada] "La anarquia y el espíritu de partido no se explican ahora por las mismas causas que se explicaban en la antigüedad, y por consecuencia no pueden ahora como entonces conducir a los mismos efectos".

75

Un análisis desde una perspectiva de los lenguajes políticos en PALTI, Elías. El momento romántico. Nación, historia y lenguajes políticos en la Argentina del siglo XIX. Buenos Aires: Eudeba, 2009.

76

ALBERDI, Juan Bautista. Doble armonia..., Op. Cit., p.129. "(...) cada pueblo, pues, tiene y debe tener su civilización propia, que ha de tomarla en la combinación de la ley universal del desenvolvimiento humano, con sus condiciones individuales de tiempo y espacio"
A young man full of talent and knowledge, says a modern author, amazed to read in each page of the classics the diary of what was happening before his eyes in the last French Revolution, had the happy idea of writing it with passages taken from these authors; and with no other work than the citing, he composed an original work. It is so certain, he adds, that there is no more truthful account, or more instructive than those of the human heart. Indeed, when we place these considerations in our dimensions, it seems that Cicero, Tacitus and Sallust have written for us. ${ }^{71}$

Although the revolution had produced an irreparable gap between past and present, the developments were still processed in the conception of Historyas magistra vitae, in the same manner as other contemporary revolutionary experiences. ${ }^{72}$

As it became more certain that the present could not be reduced into the past, this conception of history was pierced, bringing to usage a philosophy of history that explained the changes as a gradual progress of mankind from darkness into light. This does not mean that the conception of History as magistra vitae disappeared: in the early 1830s Pedro Ferré, a leader from the province of Corrientes, affirmed in a debate with local publicists about the national organization and the economic policies, "(...) that the evidence taken from history is incontestable in politics" ${ }^{173}$. By then, however, this argument was no longer irrefutable. A few months later, within a dispute that divided the federal party in Buenos Aires among pro-Rosas and anti-Rosas, a pamphlet that quoted Benjamin Constant was published claiming that "anarchy and the spirit of party are not explained now by the same reasons they were in the past, and therefore, they cannot lead now to the same effects of before" ${ }^{174}$.

The effects of this rupture between past and present that eventually broke the traditional concept of History gained corpus shortly after in the discourse of the Romantics. ${ }^{75}$ This is made clear by the use of collective singulars, such as Progress or History. These concepts contain and explain each event, their protagonist subjects, and their ruling laws as expressions of the historical movement. Differently from the Enlightment, they did not believe it to be a single and transcendent evolution guided by a universal reason: "(...) thus, each people has and must have its own civilization that will be taken in a combination of the universal law of human development and their individual conditions of time and space"76. From this historicist perspective, the people, expressed in so many social subjects, carry an immanent temporality that presides its organic evolution and makes them unique. The fact that laws govern humanity and the people does not imply a blind submission to them, since man was understood as a free and willing being. However, they did not conceive this willing as completely unconditioned. This is one of the cores of their criticism to the Enlightment, whom they accused of having wanted to introduce innovations with no regard to these "individual conditions of time and space". On the contrary, for the Romantics, the only legitimate interventions were those that expressed possibilities within the organic development of their society. This required a work of interpretation to elucidate which laws guided its movement, and they considered themselves the only ones able to perform this mission. 
Beyond all the details that could be unraveled, the most important thing is that the Romantics developed a conception of time as a historical time, expressed by a historicist language and by collective singulars such as History. The new experiences of time, the constant changes, and acceleration were no longer understood as anomalies of the revolutionary period; they began to be conceived as legitimate expressions of History, which, in its diversity and guided by the laws of progress, was irreversibly directed towards a promising, but yet unknown future. 